ФИЛОСОФИЯ

DOI: $10.17805 /$ trudy.2015.6.1

\title{
ПЕРЕХОД ОТ ПОЗИТИВИЗМА К МЕТАФИЗИКЕ В РУССКОЙ ФИЛОСОФИИ КОНЦА ХІХ ВЕКА
}

\author{
А. В. Ганин \\ (Московский гуманитарный университет)
}

\begin{abstract}
Аннотация: В работе осуществлен анализ перехода в философии от позитивизма к метафизике, актуальный как для русской философской мысли XIX-XX вв., также как и для европейской. Приведен историко-философский обзор взглядов основных представителей русской философии 80-х годов XIX в. Показана специфика антропологического и этического элементов в русской философии. Подготовлено на основе доклада на ХІІ Международной научной конференции «Высшее образование для ХХІ века» (3-5 декабря 2015 г.) в Московском гуманитарном университете.
\end{abstract}

Ключевые слова: русская философия; антропология; позитивизм; метафизика; всеединство; монодуализм

\section{THE TRANSITION FROM POSITIVISM TO METAPHYSICS IN RUSSIAN PHILOSOPHY AT THE END OF $19^{\mathrm{TH}}$ CENTURY}

\author{
A. V. Ganin \\ (Moscow University for the Humanities)
}

\begin{abstract}
The article analyses the philosophical transition from positivism to metaphysics which was relevant for both Russian and European philosophy of the 19th and 20th centuries. We provide a historical and philosophical summary of the ideas of the most prominent Russian philosophers of the 1880s, also focusing on the specificity of the anthropological and ethical constituent element in the history of Russian philosophy. The article is based on the paper given at the 12th International research conference "Higher education for the 21st century"(December 3-5, 2015) at Moscow University for the Humanities.
\end{abstract}

Keywords: Russian philosophy; anthropology; positivism; metaphysics; all-unity; monodualism

Русская философия находится в состоянии постоянного перехода: от славянофильства - к народничеству, от марксизма - к идеализму, от «Вех» - к «Смене вех». На фоне этих идеологических переходов остался малозаметным сугубо философский - от позитивизма к метафизике. Однако именно он ознаменовал становление профессиональной академической философии в России в 80-е годы XIX в.

Уместным выглядит сравнение двух философов той эпохи - B. С. Со- 
ловьева и Н. Я. Грота. Молодость обоих мыслителей пришлась на 60-70-е годы XIX в., на период расцвета на русской почве реализма, нигилизма и позитивизма. Оба испытали влияние Д. И. Писарева, Л. А. Фейербаха, Г.Спенсера. И оба же (Соловьев - к началу 1880-х, Грот - к 1886 гг.) перешли на позиции антипозитивизма.

Стоит заметить, что Владимир Сергеевич Соловьев в своей ранней работе «Кризис западной философии. Против позитивистов» (1874) оборачивает столь «модную» в то время позитивистско-нигилистическую критику против нее самой. Отчасти этим можно объяснить столь быстрый рост популярности Соловьева как философа. На фоне нигилизма как критики российской отсталости и попытки революционно-демократического подъема «снизу», Соловьев становится апологетом яростной критики Запада и западной философии «сверху».

Уже в начале философского пути Соловьев заявляет необходимость целостного, холистского подхода. Его основная философская интуиция заключается в преодолении односторонностей эмпиризма (от Ф. Бэкона до Д. Юма и позитивистов) и рационализма (от Р. Декарта до Г. В. Ф. Гегеля). Такой вариант синтетического знания Соловьев предлагал создать в рамках соединения философии, науки и религии. Так, в работе «Критика отвлеченных начал» ключевым онто-гносеологическим принципом становится принцип всеединства. Соловьев пишет о том, что «только гармонический синтез религиозного, философского и опытно-научного знания есть нормальное состояние нашей умственной жизни» (Соловьев, 2001: 25).

Николай Яковлевич Грот, будучи современником Соловьева, далеко не сразу сошелся с ним на почве критики позитивизма. Первый период творчества Грота - с 1877 по 1885 гг. - можно охарактеризовать как сугубо позитивистский. В это время он находится под сильным влиянием Г. Спенсера, В. Вундта, И. Тэна и других классиков позитивизма. Неудивительно, что в одной из первых печатных работ Грот пишет о том, что «философия есть только общее название для известного круга частных, специальных наук (как психология, теория познания, история развития мысли, т. е. история философии и т. д.)» (Грот, 1877: 6). Из этого отрывка становится понятно, что, если в вопросе психологии Грот стоит на позиции Спенсера, то относительно философии он, скорее, последователь Конта, апеллирующий к актуальности «закона трех стадий» и требующий изгнать философскую метафизику из научного дискурса.

Однако уже к 1885 г., находясь под влиянием изучения философии Б. Спинозы и Дж. Бруно, Грот совершает ᄀпостепенный переход «от позитивизма к метафизике». Шаг за шагом начинают проявляться монистические, и даже пантеистические мотивы, все больше схожие с уже упомянутыми идеями В. С. Соловьева. Так, Грот полагает, что «в данном случае, истина - в синтезе монизма и дуализма, - в доктрине, которая еще не 
имеет ныне общего названия, но проще всего может быть названа монодуалистической» (Грот, 1885: 23).

Одной из причин такого перехода является попытка соединить антропологию, этику и эстетику в единую философскую систему. На пути к этой целостности неизбежно встает вопрос о свободе воли и детерминизме. Соловьев, как мы понимаем, решил этот вопрос вполне в духе христианской философии - через соединение этики и божественной воли. Грот же стал обходить позитивизм со стороны этики и психологии (заметим, что этим же путем шел другой отечественный мыслитель 1880-х гг. - Л. М. Лопатин). Отсюда логично вытекает более поздний тезис о том, что «пантеизм примирен с теизмом, учением о личном Боге, - монизм с дуализмом, натурализм и материализм с спиритуализмом» (Грот, 1894: 25).

От прежнего позитивизма не остается и следа, он вытеснен на периферию, а на его место встает спиритуалистическая философия, основанная на идеях свободы воли и психологизма. Монодуализм Н. Я. Грота, с одной стороны, противопоставлен классическому позитивизму, уповающему на эмпиристскую методологию, с другой - мистико-религиозной публицистике Соловьева и его последователей.

Наконец, уже в XX в. мы видим в русской общественной мысли схожий пример перебежчика из одного лагеря в другой - это П. А. Сорокин. Социолог, социальный философ, начинавший свой путь в науке с неопозитивистских позиций, затем в период 30-х годов XX в., «буквально по всем основным теоретическим и методологическим принципам старой бихевиористской конструкции Сорокин производит ревизию и смену установок на прямо противоположные» (Голосенко, 1992: 95).

Эта ревизия в первую очередь обусловлена воздействием философии интуитивизма Н. О. Лосского, с которым Сорокин активно сотрудничал в эмиграции. Лосский, будучи учеником Соловьева, повел П. Сорокина по пути этической и интуитивистской философской установки. И в итоге из автора, который о метафизике отзывался не иначе как о чем-то малопонятном и путаном, Сорокин превратился в исследователя «творческого альтруизма», «силы любви» И «молитвы» и многих других концептов его позднего творчества.

В одной из статей 1915 г Сорокин уничижительно вопрошал «Читатель! Вы понимаете? Я, каюсь, нет. Впрочем, я понимаю одно, что в эти фразы можно всунуть любое содержание: и бога, и сатану. Так пишут философы» (Сорокин, 1992: 245). В «Социальной и культурной динамике» Сорокин уже говорит иначе, полагая, что гармоничное единство должно быть связано с синтезом «истины веры» и «истины ощущений» под водительством «истины разума» (Сорокин, 2006: 287).

В чем же причины столь частых переходов и метаний от позитивизма к метафизике? Почему и Соловьев, и Грот, и Сорокин, и основатель 
европейского позитивизма О. Конт, все перешли на метафизические позиции? Постараемся суммировать все варианты ответов:

1. Марксистский ответ: предполагается, что все авторы-позитивисты являются скрытыми апологетами буржуазного класса, следовательно, сталкиваясь с революционной ситуацией $(1848,1881,1917$ гг.) - неизбежно займут позицию реакционную, религиозную и консервативную;

2. Психологический ответ: предполагается, что авторы не смогли избежать религиозно-психологического кризиса личности, что привело к трансформации их философских систем. Интеллектуализм уступил место мистицизму и иррационализму, особенно в форме интуитивистской философии А. Бергсона и Н. О. Лосского;

3. Этико-эстетический ответ: предполагается, что авторы-позитивисты, сталкиваясь с проблемами эстетики и этики, не смогли выработать целостного мировоззрения и при этом избежать около религиозной позиции. Упор делается на античный принцип калокагатии и триединства истины, добра и красоты, принцип гармонии между чувствами, мыслями и действиями;

4. Субстанциональный ответ: предполагается, что установка на субстанциональный монизм и цельность знания (рассуждения о мире/человечестве в целом у Конта, или всеединстве у Соловьева) с неизбежностью ведет к метафизической концепции.

Таким образом, путь из позитивистов в метафизики является одним из наиболее значимых и проторенных в русской философской традиции. На мой взгляд, он связан с попыткой преодолеть односторонность позитивизма - или религиозно, что вело по пути философии всеединства и софиологии Соловьева, или этико-психологически, что легло в основу факультетской философии 80-90-х гг. XIX в. Последний вариант должной популярности, впрочем, как и вдумчивого исследования, до сих пор не получил.

\section{СПИСОК ЛИТЕРАТУРЫ}

Голосенко, И. А. (1992) Социология Питирима Сорокина (русский период деятельности). Самара : социологический центр «Социо».

Грот, Н. Я. (1885) Джиордано Бруно и пантеизм. Одесса : Типография «Одесского вестника».

Грот, Н. Я. (1877) Козлов. Философские этюды: критический очерк. Киев : Типография В. Давиденко.

Грот, Н. Я. (1894) Основные моменты в развитии новой философии. М. : Посредник.

Соловьев, В. С. (2001) Критика отвлеченных начал // Соловьев В. С. Полное собрание сочинений и писем : в 20 т. М. : Наука. Т. 3.

Сорокин, П. А. (2006) Социальная и культурная динамика. М. : 
Астрель.

Сорокин, П. А. (1992) Человек. Цивилизация. Общество. М. : Издательство политической литературы.

Ганин Александр Владиславович - аспирант кафедры философии, культурологии и политологии Московского гуманитарного университета. Адрес: 111395, г. Москва, ул. Юности, д. 5. Эл. Адрес: avg_socio@mail.ru. Научный руководитель - д-р филос. н., проф. Т. А. Горелова.

Ganin Aleksander Vladislavovich, Postgraduate student, Department of Philosophy, Culturology and Politology, Moscow University for the Humanities. Postal address: 5 Yunosti St., 111395 Moscow, Russian Federation. E-mail: avg_socio@mail.ru. Research adviser - T. A. Gorelova, Doctor of Philosophy, Professor. 